\title{
Heat Pump Heating System Development of Educational Building based on Energy, Economical and Environmental Impacts
}

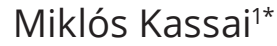 \\ 1 Department of Building Service Engineering and Process Engineering, Faculty of Mechanical Engineering, \\ Budapest University of Technology and Economics, H-1111 Budapest, Muegyetem rkp. 3., Hungary \\ * Corresponding author, e-mail: kas.miklos@gmail.com
}

Received: 12 February 2019, Accepted: 19 March 2019, Published online: 20 May 2019

\begin{abstract}
In this research the technical designing of energy efficient heating system with vertical-borehole heat pumps for institutional buildings was performed. The local government would like to change the old gas boiler-based heat producing system to up-to-date, environmental friendly equipment with the financial support of the European Union. The payback time was calculated and environmental calculations were achieved with carbon dioxide saving by various conditions that were also achieved during the research project. The results show that the heat pump system also provides a significant reduction of environmental load, in addition to significant energy savings. The amount of calculated savings justifies the environmental friendliness of heat pump systems.
\end{abstract}

Keywords

heat pump, energy design, energy saving, carbon dioxide saving, harmful substances saving

\section{Introduction}

Buildings are responsible for about $40 \%$ of the total energy consumption in most EU countries. Similarly to other developing counties in Hungary, more than $60 \%$ of the existing buildings are older than 40 years. A rapid and substantial energy retrofit process is required for these existing and old buildings [1-3]. The EU Directive 2010/31/EU requires buildings, or parts of buildings, to meet a minimum energy performance or be subject to a retrofit or refurbishment [4-6]. These requirements may be met by renovating a building's envelope and HVAC systems [7-11]. The stability of indoor air parameters is also a very important factor, essential for such institutions, schools, hospitals and also museums. Nowadays the use of renewable energy for space heating became one of the top priorities in modern building design [12-18].

In Hungary, the geological possibilities provide excellent grounds for using geothermal building engineering systems. Regrettably, however, even the environmentally aware people tend to forget this. One of these possibilities is the heat pump. Despite its broad applicability and practically infinite process medium (primary side), its application is not sufficiently widespread in the Hungarian building engineering field, even though it allows for the generation of the desired thermal conditions of comfort zones with low operation cost-whether it is used for heating or refrigeration. It can also be used for the preparation of domestic hot water, and thus, it is an excellent method for disadvantaged municipalities (for example) to provide low-cost and environment-friendly heating and air conditioning for the buildings they operate.

The purpose of the research is to determine the optimum operating condition for a vertical-borehole system, which can be used to create appropriate comfort parameters for people who are particularly sensitive to the conditions (children).

The specific topic of the research work is the supply of the heating system for the kindergarten, elementary school and day-care buildings in Tiszagyenda with a vertical-borehole system installed in the soil. The aim is to prepare these buildings to meet the needs of students and workers spending their days there in a modern manner with low operating costs and high comfort levels as opposed to the boiler-based heating currently in use. The town wishes to apply for EU funds to finance the utilization of the potential offered by the good geothermal characteristics of the area. To reduce the costs, the heating 
systems currently in use should be modified as minimally as possible while the expectation is to have them operate as efficiently and with as low operating costs as possible. Chief engineer Zoltán Fodor and at Geowatt Ltd. and Peter Orban MSc. student [19] have been a huge help in the realization of the project with their expert advice which contributed to the success of this research study.

\section{Thermo processing sizing of the building}

The aim of the task is to ensure optimal comfort parameters in the three buildings (Table 1) of the kindergarten (address: Tiszagyenda, Ady Endre street 6., H-5233, Hungary), elementary school, and day-care in the city of Tiszagyenda by using a vertical-borehole heat pump system. It is also a goal to keep the current high-temperature-level system.

The operation of each institution is intermittent, scheduled for up to 12 hours a day, so they do not require 24-hour heating. Based on the input data provided, the buildings (with the exception of the gym) were built in the 1970 s, and their structure was probably constructed using bricks or loam. The building of the gym was constructed in 2010 from funds the town applied for. The building of the day-care is heated with gas convectors, the building of the junior class uses cast-iron radiators while slimline radiators are used for the senior class and the gym; using one gas boiler heat core per building. The junior class and the gym are on the same circuit whose hydraulic control is currently not available; the former implementation was unprofessional. The owner requested not to replace the heat emitters if possible. Therefore, the radiators remain the same in case of the junior class and the senior class. Due to the currently known state of the gym in the service rooms, it is necessary to replace the current heat emitters with larger ones, and fan coils should be used in the arena due to the interior height. Of course, the gas convector system will be removed from the day-care, and slimline radiators will be installed instead.

It is also important to note that the buildings will be updated in terms of energetics, the wall and slab structures will be insulated in accordance with the Hungarian building energy standard (Decree No. 7/2006) in line with

Table 1 Data of the institutions to be heated in the settlement

\begin{tabular}{lcc}
\hline Designation of the building & Floor area $\left[\mathrm{m}^{2}\right]$ & $\begin{array}{c}\text { Air volume to be } \\
\text { heated }\left[\mathrm{m}^{3}\right]\end{array}$ \\
\hline Junior class and gym & 854 & 4704.2 \\
Senior class & 336 & 1007.2 \\
Day-care & 121.5 & 289.9 \\
\hline
\end{tabular}

the cost-optimized requirements and the doors and windows will be replaced as well. Except for the gym which is the most modern of the buildings; since it was built from funds the town applied for, it is currently in the sustained stage, and the law does not allow it to be modified.

Based on the data provided by the municipality, the heat demand of each building was calculated with the following result (Table 2).

The thermo processing sizing - to facilitate a smooth design process - was performed with the extremely userfriendly WinWatt program widely used in the industry; it performs the energetics sizing in accordance with the current version of the Hungarian building energy standard (Decree No. 7/2006) [20] and the thermo processing sizing in accordance with Standard MSZ 04-140/2-1991 [21].

\section{Development of the engineering system}

\subsection{Heat pump selection}

In general, the following parameters were taken into account for selecting the heat pump equipment:

- Calculated power demands,

- Temperature levels to be used,

- Direct and indirect functions to be performed (heating, refrigeration, DHW production),

- Heat pump controllability, system integration.

Based on these, the heat pumps for each building can be selected. As the current heat emitters remain largely unchanged, a $60 / 53{ }^{\circ} \mathrm{C}$ temperature difference had to be taken into account for energetical modernization sizing.

Based on the data obtained during the sizing, the following heat pumps were selected for the energy supply of the individual buildings (Table 3 ).

\begin{tabular}{lc} 
Table 2 Heat demand of the individual buildings \\
\hline Location & Heat demand $[\mathrm{kW}]$ \\
Senior class & 21.498 \\
\hline Junior class & 20.228 \\
Gym & 44.466 \\
Day-care & 8.866 \\
\hline TOTAL & 95.058 \\
\hline
\end{tabular}

Table 3 The selected heat pumps

\begin{tabular}{lcc}
\hline Name of the heat core & $\begin{array}{c}\text { Heating power } \\
\text { demand }[\mathrm{kW}]\end{array}$ & Chosen heat pump \\
\hline Senior class and gym & 65.964 & $\begin{array}{c}\text { Vaporline } \\
\text { GBI66-HW } \\
\text { Vaporline } \\
\text { Junior class and day-care }\end{array}$ \\
\hline
\end{tabular}


The main parameters of the Vaporline GBI-HW (developed and manufactured in Hungary) heat pumps are as follows according to the manufacturer:

- EVI cycle compression,

- Equipped with EEV valve and refrigerant tank,

- A weather-based digital control equipment provides the most efficient operation, the monitoring and protection functions,

- The maximum available heating delivery temperature is $63{ }^{\circ} \mathrm{C}$,

- Wide heating power range,

- Can be used in low- and high-temperature heating systems as well,

- It is also suitable for the production of domestic hot water, equipped with desuperheater,

- Especially silent operation.

The main technical parameters and data of the heat pumps (Fig. 1) supplied by the manufacturer are shown in Table 4.

Table 4 Main technical parameters and

data of the chosen heat pumps [22]

\begin{tabular}{lcc}
\multicolumn{3}{c}{ data of the chosen heat pumps $[22]$} \\
\hline & $\begin{array}{c}\text { Vaporline } \\
\text { GBI66-HW }\end{array}$ & $\begin{array}{c}\text { Vaporline } \\
\text { GBI48-HW }\end{array}$ \\
\hline Heating power $0 / 35^{\circ} \mathrm{C}[\mathrm{kW}]$ & 64.8 & 47.6 \\
Heating power $0 / 63{ }^{\circ} \mathrm{C}[\mathrm{kW}]$ & 65.4 & 49 \\
Electric power demand $0 / 35^{\circ} \mathrm{C}[\mathrm{kW}]$ & 14 & 10.1 \\
$\begin{array}{l}\text { Electric power demand } 0 / 63{ }^{\circ} \mathrm{C}[\mathrm{kW}] \\
\text { COP 0/35 }{ }^{\circ} \mathrm{C}\end{array}$ & 25.2 & 19.1 \\
COP 0/63 ${ }^{\circ} \mathrm{C}$ & 4.6 & 4.7 \\
$\begin{array}{l}\text { Evaporator-side volumetric flow rate } \\
\text { demand }[1 / \mathrm{min}]\end{array}$ & 2.6 & 2.6 \\
$\begin{array}{l}\text { Heating-side volumetric flow rate } \\
\text { demand }[1 / \mathrm{min}]\end{array}$ & 204 & 150 \\
\hline
\end{tabular}

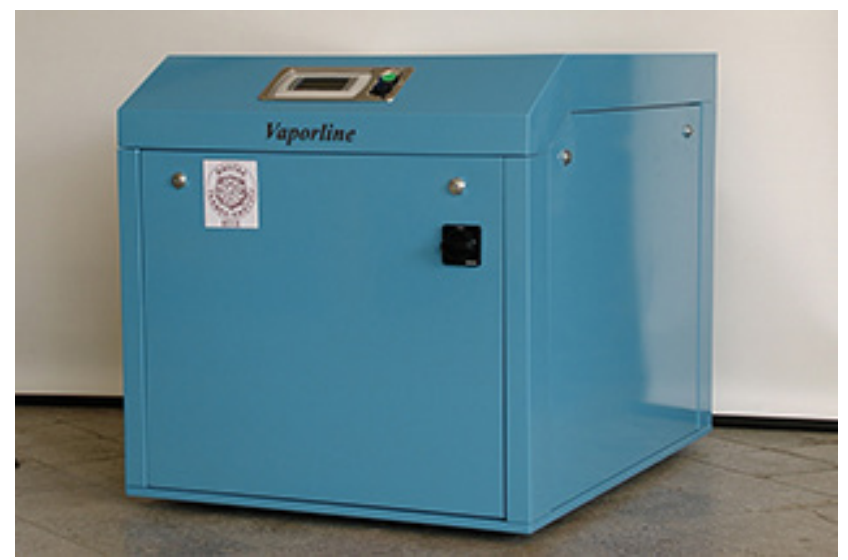

Fig. 1 Vaporline type heat pump equipment [22]
Taking into account the technical data summarized in the tables, the total volumetric flow rate demand of the planned system on the evaporator side of the heat pumps: $354 \mathrm{l} / \mathrm{min}$.

\subsection{Probe system sizing}

Probe system sizing was performed with the design software of GLD Design. When the input parameters are entered, the required probe length can be easily determined, and the long-term thermal effect analysis can be easily performed with the help of the program.

In case of the senior class / gym circuit and based on the entered parameters, ten probes each with a depth of $100 \mathrm{~m}$ are required for the chosen heat pump to function adequately. In this case, the Seasonal Coefficient of Performance (SCOP) assumes a value of 4.4, while the temperature of the probe does not drop below an average of $5{ }^{\circ} \mathrm{C}$. The thermal analysis shows that the soil will cool to $14.2^{\circ} \mathrm{C}$ in 25 years in the vicinity of the probe assuming there is no heat input during summer. (Since the system will only have heating functionality, but no refrigeration functionality.) In 25 years later, the thermal performance will decrease, but not so much that would influence the heating capacity of the conditioned spaces.

In case of the junior class / day-care circuit, the calculated number of probes is nine, and the probe depth is 100 meters. In this case the SCOP value is 4.4. The temperature of the probe does not drop below an average of $5.5^{\circ} \mathrm{C}$, and the soil is expected to cool down to $14.6^{\circ} \mathrm{C}$ in 25 years. The results obtained during the sizing of the probe system are summarized in Table 5.

\subsection{Hydraulic dimensioning of the engineering system}

The hydraulic dimensioning of the system was also performed using WinWatt. With the exception of the day-care, the network will not be modified significantly. Equipping

Table 5 Extract from the results of the probe sizing

\begin{tabular}{lcc}
\hline & $\begin{array}{c}\text { Senior class } \\
+ \text { gym }\end{array}$ & $\begin{array}{c}\text { Junior class } \\
+ \text { day-care }\end{array}$ \\
\hline Total probe length $[\mathrm{m}]:$ & 894.3 & 850.3 \\
Number of probes [pcs] & 10 & 9 \\
Required probe depth [m] & 89.4 & 94.5 \\
Real probe depth $[\mathrm{m}]$ & 100 & 100 \\
Soil temperature change $\left[{ }^{\circ} \mathrm{C}\right]$ & -0.8 & -0.4 \\
Total capacity $[\mathrm{kW}]$ & 160.8 & 145.3 \\
Peak demand $[\mathrm{kW}]$ & 3.6 & 3.7 \\
Heat pump COP & 4.5 & 4.8 \\
System COP & 4.4 & 4.4 \\
\hline
\end{tabular}


the radiators with thermostatic valves and return union nuts is part of the investment. Another change is that the radiators are replaced by fan coils in the gym.

In case of the junior class/day-care circuit, three Danfoss ASV-I adjusting valves will be installed. In case of the daycare, an entirely new radiator system will be installed.

Choosing an appropriate circulation pump is essential for the operation of the system. Separate circulation pumps were chosen for each circuit. In case of the senior class and the gym the design resistance is: $60 \mathrm{kPa}$, the required mass flow rate to be transported is $12.2 \mathrm{~m}^{3} / \mathrm{h}$. Thus, the design resistance corresponds to the value of a water column of 6 $\mathrm{m}$, so a pump with at least the same delivery head should be selected. The Grundfos MAGNA1 40-100F pump was chosen using the sizing software of Grundfos water pump selection tool. The chosen pump in case of the junior class and the day-care: Grundfos MAGNA1 40-80F. The chosen pumps are suitable for maintaining the pressure levels of the networks and can be connected to a building management system, and thus, they are suitable for programming modern pressure control methods. For operational safety reasons, two pumps are installed in parallel, and only one will be operational at any given time. The other is expected to ensure continuous operation during maintenance and in case of failures.

A circulation pump has to be installed on the ground side as well. Based on the available volumetric flow rate data and the delivery heads, the technical parameters of the pumps selected using the Grundfos sizing program are shown in Table 6.

CR type vertical-axis pumps are capable of operating with a wide-temperature-range medium. They are used in water supply and industrial areas, including high-pressure or -temperature and even aggressive, hazardous media. According to today's requirements, the controller can change operating parameters of the pump according to the system demands. Two pumps will be installed in parallel in each circuit. Only one will be operational at any given time; the other is expected to ensure continuous operation during maintenance and in case of failures.

The sected standard buffer tank sizes selected based on the determination of the buffer capacity (Table 7) are shown in Table 8.

However, during the planning work, it was found that because of lack of space it is not possible to install two separate buffer tanks as later domestic hot water supply is a required option, too, the installation of the hot water tank also has a need for installation space but the dimensions

\begin{tabular}{lcccc}
\multicolumn{5}{c}{ Table 6 Ground-side pumps } \\
\hline Heat core & $\begin{array}{c}\text { Pump } \\
\text { type }\end{array}$ & $\begin{array}{c}\text { Mass flow } \\
\text { rate }\left[\mathrm{m}^{3} / \mathrm{h}\right]\end{array}$ & $\begin{array}{c}\text { Delivery } \\
\text { head }[\mathrm{m}]\end{array}$ & $\begin{array}{c}\text { Electric power } \\
\text { consumption }[\mathrm{W}]\end{array}$ \\
\hline $\begin{array}{l}\text { Senior class } \\
+ \text { gym }\end{array}$ & CR 10-2 & 12.2 & 15.2 & 780 \\
$\begin{array}{l}\text { Junior class } \\
+ \text { Day-care }\end{array}$ & CR 5-4 & 9 & 15 & 580 \\
\hline
\end{tabular}

Table 7 Required capacity for the buffer tank

\begin{tabular}{lcc}
\hline Heat core & $\begin{array}{c}\text { Power demand } \\
{[\mathrm{kW}]}\end{array}$ & $\begin{array}{c}\text { Minimum buffer tank } \\
\text { size required [1] }\end{array}$ \\
\hline Senior class + gym & 64.8 & 648 \\
Junior class + day-care & 47.6 & 476 \\
\hline
\end{tabular}

Table 8 Chosen buffer tank sizes

\begin{tabular}{lc}
\hline Heat core & Buffer tank size [1] \\
\hline Senior class + gym & 800 \\
Junior class + day-care & 500 \\
\hline
\end{tabular}

of the heating center to be installed are limited and the available financial background is also narrower. For this reason, the two heat pumps supply a common storage tank with a volume of 1500 liters, which is the smallest standard size available, but which satisfies the energy needs.

A new thermal center building is being set up for the heat pumps near the day-care center building. The heat pump equipment of each building are installed there. The main cables to each building shall enter through the existing heating rooms as far as possible.

\section{Examining return and profitability rates}

The costs of the engineering project with the heat pump system based on the development plans can be seen in Table 9.

The costs shown in Table 9 also include the costs of commissioning in addition to the thermal center equipment and materials.

According to the local government's data supply [19], the current system's natural gas consumption $\left[\mathrm{Nm}^{3}\right]$ and electricity consumption $[\mathrm{kWh}]$ are known. Data can be used directly for cost estimation, but the amount of natural gas will be needed later, in $\mathrm{kWh}$ units, too, so it is worth calculating with Eq. (1):

$V_{\text {fuel }}=\frac{E_{e x t}}{H}$

where $E_{\text {ext }}$ is the extracted heat in $\mathrm{kWh}, H$ is the caloric value in $\mathrm{kWh} / \mathrm{Nm}^{3}$.

For natural gas, the calorific value is $9.44 \mathrm{kWh} / \mathrm{Nm}^{3}$. By rearranging Eq. (1), natural gas consumption can be calculated by Eq. (2): 
$E_{\text {ext }}=V_{\text {fuel }} \cdot H$.

Based on the available consumption data, the evaluation of the energy consumption of the current system was determined, the results are shown in Table 10.

The municipality currently receives natural gas at a price of $0.4 € / \mathrm{Nm}^{3}$ and electricity at $0.126 € / \mathrm{kWh}$. The primary energy costs determined on the basis of data provided during the collection of data are shown in Table 11.

In case of the planned heat pump system, the use of natural gas for heating purposes would cease completely. For the heat pump systems, the city would receive electricity at a price of $0.08 € / \mathrm{kWh}$. (Prices are preliminary prices for the time being.) The electric energy consumption produced from fossil fuels required for the operation of heat pumps and the costs are shown in Table 12.

Based on the current consumption as outlined in Table 10 and the planned consumption in Table 12, the annual energy savings can be determined using Eq. (3).

$Q_{\text {sav }}=Q_{\text {curr }}-Q_{\text {planned }}=286511-41270=245241 \mathrm{kWh}$.

Table 9 The investment cost of the heat pump system

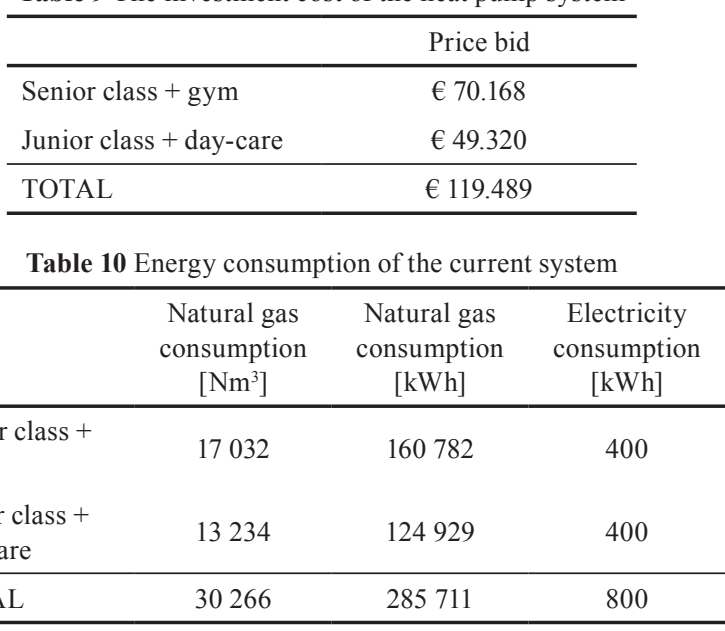

Table 11 The cost of primary energy in the current system

\begin{tabular}{lcc}
\hline Location & $\begin{array}{c}\text { Cost of natural } \\
\text { gas use }[€]\end{array}$ & $\begin{array}{c}\text { Cost of fossil } \\
\text { electric energy }[€]\end{array}$ \\
\hline Senior class + gym & 6.812 & 50 \\
Junior class + day-care & 5.291 & 50 \\
\hline TOTAL & 12.103 & 100 \\
\hline
\end{tabular}

Table 12 Energy consumption of the planned heat pump system and its cost

\begin{tabular}{lcc}
\hline Location & $\begin{array}{c}\text { Fossil. electr. energy } \\
\text { consumption }[\mathrm{kWh}]\end{array}$ & $\begin{array}{c}\text { Energy } \\
\text { cost }[€]\end{array}$ \\
\hline Senior class + gym & 23.224 & 1.780 \\
Junior class + day-care & 18.046 & 1.383 \\
\hline TOTAL & 41.270 & 3.163 \\
\hline
\end{tabular}

The annual cost of energy saved (taking into account that natural gas-fired heating is fully replaced) can be determined by Eq. (4).

$K_{\text {sav }}=K_{\text {curr }}-K_{\text {planned }}=12.203-3.163=9.040 €$.

The results for the annual cost of energy saved can be seen on Fig. 2.

Taking into account the investment cost described in point 1, the return period can be determined using Eq. (5).

$t_{\text {sav }}=\frac{K_{\text {invest }}}{K_{\text {sav }}}=\frac{119.489}{9.040}=13.21$ years.

As you can see, this is not necessarily a fast-return investment. The return period calculated corresponds to the expected value of similar investments, calculating only the investment cost and the energy savings.

The return is considerably reduced if we consider that the current system should be replaced in any case, due to obsolescence, operational safety problems, and component service problems. It is therefore appropriate to compare how much the return would be by comparing the cost of installing a modern condensing boiler system and the planned heat pump system.

\section{Examining environmental indicators}

Besides saving energy, the investment has significant environmental impacts, too. This can be most clearly illustrated by the carbon dioxide and other combustion product components (nitrogen oxides, carbon monoxide) emitted by unused fuel.

The calculation theory used in research is based on the amount of energy needed to meet the needs, originating from burning fuels (natural gas, fossil fuels). In the case of carbon dioxide, the energy consumption modified by the efficiency of the burning devices determines the amount of energy consumed if the calorific value of the fuel is known.

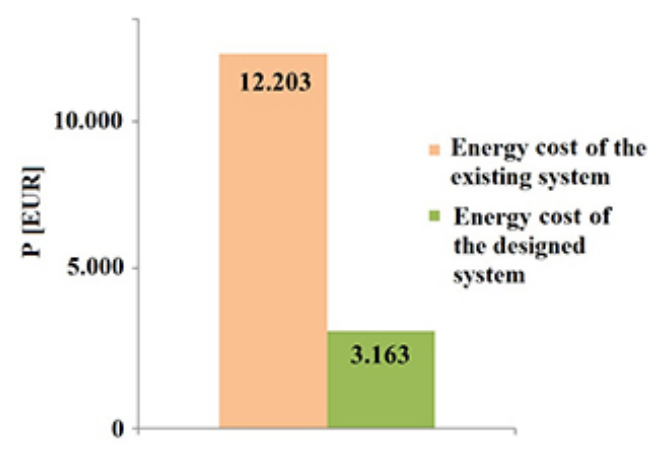

Fig. 2 Comparison of the energy costs of the existing and developed engineering systems 
For natural gas (as in this case), the amount of $\mathrm{CO}_{2}$ emitted can be determined as follows:

$t_{\mathrm{CO}_{2}}=V_{\text {fuel }} \cdot \frac{11.13}{10} \cdot \rho \cdot \frac{1}{1000}$.

For natural gas, the caloric value is $9.44 \mathrm{kWh} / \mathrm{Nm}^{3}$, and the density is $1.9768 \mathrm{~kg} / \mathrm{m}^{3}$. The burning of each $10 \mathrm{~m}^{3}$ of natural gas produces $11.13 \mathrm{~m}^{3}$ of carbon dioxide. The quotient is therefore used to determine the amount of carbon dioxide generated from combusted natural gas.

Equation (7) is used for nitrogen oxides and carbon monoxide production:

$t_{i}=1.5 \cdot t_{i, p e r m} \cdot E_{\text {cons }}$.

For nitrogen oxides, the permissible value is $200 \cdot 10^{-9} \mathrm{t} / \mathrm{kWh}$ and for carbon monoxide this is $100 \cdot 10^{-9} \mathrm{t} / \mathrm{kWh}$. Table 11 shows that the amount of energy consumed is $285711 \mathrm{kWh}$. For the current existing and operating system, the cumulative emissions are shown in Table 13.

In the case of heat pump systems, the equations for $\mathrm{NO}_{\mathrm{x}}$ and $\mathrm{CO}$ may be used in the same way. For the determination of $\mathrm{CO}_{2}$ emissions, the following equation shall apply according to the current regulations applied for tenders:

$t_{\mathrm{CO}_{2}}=0.93 \cdot E_{\text {ope }}$.

The electrical energy [kWh] required (Table 14) for the operation of the heat pump system can be determined by Eq. (9):

$$
E_{\text {ope }}=\frac{Q_{h}}{\mathrm{SCOP}} \text {. }
$$

The amount of carbon dioxide produced by the electric power consumption of the current gas boiler and the planned heat pump system is summarized in Fig. 3.

\section{Conclusion}

The system in its current form will only be built for heating. Later on, if there is a need for this, and there will be financial resources for the local government, it may be worth thinking about producing domestic hot water (partly) with the heat pump, along with heating. The solution for this is the application of the desuperheater. The planned heat pumps have the necessary equipment to regain the extra heat of overheating. This heat quantity is perfectly suited for the production of domestic hot water. The disadvantage is that the current water supply network would require significant transformation, the cost of which cannot be neglected either.
Table 13 Emission of harmful substances by the current system compared to the entire system

\begin{tabular}{lc}
\hline Cumulative energy consumption $[\mathrm{kWh}]$ & 285711 \\
\hline Consumed natural gas $\left[\mathrm{Nm}^{3}\right]$ & 30266 \\
$\mathrm{CO}_{2}$ emissions [t/a] & 66.59 \\
NOx emissions [t/a] & 0.086 \\
CO emissions [t/a] & 0.043 \\
\hline
\end{tabular}

Table 14 Electric energy required for the operation of heat pumps

\begin{tabular}{lc}
\hline Heat core & $\mathrm{E}_{\text {ope }}[\mathrm{kWh}]$ \\
\hline Senior class + gym & 23638.26 \\
Junior class + day-care & 10449.24 \\
\hline TOTAL & 34087.5 \\
\hline
\end{tabular}

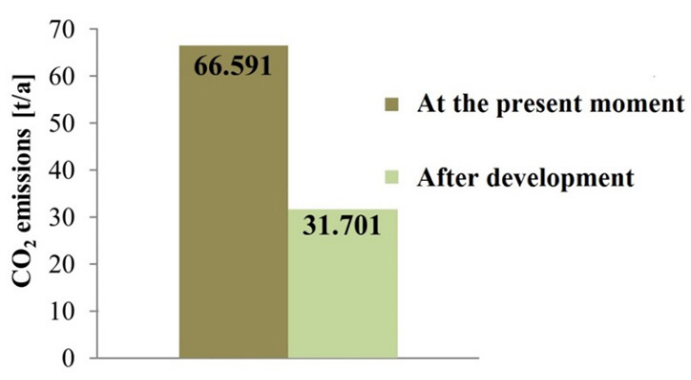

Fig. 3 Comparing the carbon dioxide production of the existing and developed systems

The application of the system for cooling would not be appropriate under these conditions. Passive cooling must be discarded due to high summer heat gains and the large size of the buildings, and most of the heat generators are not suitable for cooling purposes, either. This factor also prevents active cooling. It would also be very costly to put it into operation (replacement of heat exchangers and the construction of a new pipeline network), for which the municipality has no financial sources of its own, and EU funds are not, in principle, available for such purposes. The increased energy output from cooling could of course be utilized either for the production of domestic hot water, but it would probably require substantial reconstruction, with relatively low returns and additional investment growth.

In addition to reducing the energy consumption to be achieved by the planned engineering system, the use of solar cells would be an additional economic investment for the development of the system, which could generate electricity and achieve additional energy consumption reduction.

\section{Acknowledgment}

This research project was financially supported by the National Research, Development and Innovation Office from NRDI Fund [grant number: NKFIH PD_18 127907], 
the János Bolyai Research Scholarship of the Hungarian Academy of Sciences, and the ÚNKP-18-4 New National Excellence Program of the Ministry of Human Capacities, Budapest, Hungary. Moreover the research reported in this

\section{References}

[1] Capozzoli, A., Grassi, D., Causone, F. "Estimation models of heating energy consumption in schools for local authorities planning", Energy and Buildings, 105, pp. 302-313, 2015.

https://doi.org/10.1016/j.enbuild.2015.07.024

[2] Prada, M., Popescu, D. E., Bungau, C., Pancu, R., Bungau, C. "Parametric Studies on European 20-20-20 Energy Policy Targets in University Environment", Journal of Environmental Protection and Ecology, 18(3), pp. 1146-1157, 2017.

[3] Sarrade, L., Manificat, A., Corgier, D., Burgun, F. "The GENHEPI Concept: a New Methodology for Low Energy Consumption Building Renovation Demonstration Program", Energy and Environment, 2, pp. 1-6, 2016.

[4] Nyers, A., Pek, Z., Nyers, J. "Dynamical Behaviour of a Heat Pump Coaxial Evaporator Condensing the Phase Border's Impact on Convergence", Facta Universitatis, Series: Mechanical Engineering, 16(2), pp. 249-259, 2018. https://doi.org/10.22190/FUME180424019N

[5] Januševičius, K., Streckienė, G., Bielskus, J., Martinaitis, V. "Validation of Unglazed Transpired Solar Collector Assisted Air Source Heat Pump Simulation Model", Energy Procedia, 95, pp. 167-174, 2016. https://doi.org/10.1016/j.egypro.2016.09.039

[6] Ghazanfari, S. A., Wahid, M. A. "Heat Transfer Enhancement and Pressure Drop for Fin-and-Tube Compact Heat Exchangers with Delta Winglet-Type Vortex Generators", Facta Universitatis, Series: Mechanical Engineering, 16(2), pp. 233-247, 2018. https://doi.org/10.22190/FUME180117024G

[7] Takács, J., Straková, Z., Rácz, L. " Costs Analysis of Circulation Pumps for Heating of Residential Building", Periodica Polytechnica Mechanical Engineering, 62(1), pp. 10-15, 2018.

https://doi.org/10.3311/PPme.10606

[8] Takács, J. "Possibility of Geothermal Water's Using in Geothermal Energy Systems", Periodica Polytechnica Mechanical Engineering, 61(4), pp. 272-275, 2017.

https://doi.org/10.3311/PPme.10546

[9] Rasheed, A., Lee, J. W., Lee, H. W. "Development and Optimization of a Building Energy Simulation Model to Study the Effect of Greenhouse Design Parameters", Energies, 11(8), pp. 1-19, 2018. https://doi.org/10.3390/en11082001

[10] Jedlikowski, A., Anisimov, S., Danielewicz, J., Karpuk, M., Pandelidis, D. "Frost formation and freeze protection with bypass for counter-flow recuperators", International Journal of Heat and Mass Transfer, 108(Part A), pp. 585-613, 2017. https://doi.org/10.1016/j.ijheatmasstransfer.2016.12.047

[11] Valiño, V., Rasheed, A., Tarquis, A. M., Perdigones, A. "Effect of increasing temperatures on cooling systems. A case of study: European greenhouse sector", Climatic Change, 123(2), pp. 175187, 2014.

https://doi.org/10.1007/s10584-013-1051-6 paper was supported by the Higher Education Excellence Program of the Ministry of Human Capacities in the frame of Biotechnology research area of Budapest University of Technology and Economics (BME FIKP-BIO).

[12] Anjomshoaa, Salmanzadeh, M. "Finding a criterion for the pressure loss of energy recovery exchangers in HVAC systems from thermodynamic and economic points of view", Energy and Buildings, 166, pp. 426-437, 2018. https://doi.org/10.1016/j.enbuild.2018.02.016

[13] Gaujena, B., Borodinecs, A., Zemitis, J., Prozuments, A. "Influence of Building Envelope Thermal Mass on Heating Design Temperature", IOP Conference Series: Materials Science and Engineering, 96, Article ID: 012031, 2015. https://doi.org/10.1088/1757-899X/96/1/012031

[14] Janković, A., Antunović, B., Preradović, L. "Alternative method for on site evaluation of thermal transmittance, Facta Universitatis Series: Mechanical Engineering", 15(2), pp. 341-351, 2017. https://doi.org/10.22190/FUME170419017J

[15] Đorđević, M., Stefanović, V., Vukić, M., Mančić, M. "Experimental investigation of the convective heat transfer in a spirally coiled corrugated tube with radiant heating", Facta Universitatis Series: Mechanical Engineering, 15(3), pp. 495-506, 2017. https://doi.org/10.22190/FUME171001027D

[16] Javadi, H., Mousavi Ajarostaghi, S. S., Rosen, M. A., Pourfallah, M. "A Comprehensive Review of Backfill Materials and Their Effects on Ground Heat Exchanger Performance", Sustainability, 10(12), Article ID: 4486, 2017. https://doi.org/10.3390/su10124486

[17] Ramadan, M., Lemenand, T., Khaled, M. "Recovering heat from hot drain water - Experimental evaluation, parametric analysis and new calculation procedure", Energy and Buildings, 128, pp. 575-582, 2016. https://doi.org/10.1016/j.enbuild.2016.07.017

[18] Atmaca, İ., Kocak, S. "Theoretical energy and exergy analyses of solar assisted heat pump space heating system", Thermal Science, 18(2), pp. 417-427, 2014. https://doi.org/10.2298/TSCI120813024A

[19] Orban, P. "Intézményi épületek energiahatékony fütésrendszerének tervezése zárt szondás hőszivattyúkkal" (Designing of energy effective heating systems of institution buildings with heat pumps), MSc Thesis, Budapest University of Technology and Economics, 2018. (in Hungarian)

[20] "7/2006. (V. 24.) TNM rendelet az épületek energetikai jellemzőinek meghatározásáról" (7/2006 (V. 24). Degree of Minister Without Portfolio About Determination of Energy Efficiency of Buildings), [online] Available at: http://net.jogtar.hu/jr/gen/hjegy_doc.cgi?docid=A0600007.TNM [Accessed: 19 March 2019] (in Hungarian)

[21] Hungarian Standards Institution "MSZ 04-140/2-1991 Épületek és épülethatároló szerkezetek hőtechnikai számításai. Hőtechnikai méretezés" (Power engineering. Dimensioning calculations of buildings and building envelope structures), MSZT, Budapest, 1991. (in Hungarian)

[22] Geowatt Ltd. "Online product catalogue", 2018. [online] Available at: https://www.geowatt.hu/ [Accessed: 10 May 2018] 